\title{
PENGUATAN EFEKTIVITAS PEMBELAJARAN MELALUI EFIKASI DIRI DAN SUPERVISI KEPALA SEKOLAH
}

\author{
Papat $^{a)}$, Griet Helena Laihad ${ }^{b)}$, Yossa Istiadi ${ }^{b *}$ \\ a) SDN Kopo 3 Kabupaten Bogor, Bogor, Indonesia \\ ${ }^{b)}$ Universitas Pakuan, Bogor, Indonesia \\ *) e-mail korespondensi: papat.papat1968@gmail.com
}

Riwayat artikel : diterima: 06 November 2020; direvisi: 16 November 2020; disetujui: 06 Desember 2020

\begin{abstract}
Abstrak. Penelitian ini bertujuan untuk menemukan upaya-upaya yang dapat dilakukan dalam rangka meningkatkan Efektivitas Pembelajaran melalui kajian terhadap hubungannya dengan Efikasi Diri dan Supervisi Kepala Sekolah. Populasi penelitian ini berjumlah 163 guru PNS, dengan jumlah sampel sebanyak 116 guru, yang penentuannya menggunakan rumus Slovin dengan toleransi kesalahan sebesar 5\%. Data dikumpulkan menggunakan instrumen dalam bentuk kuesioner dan dianalisis dengan analisis statistik deksriptif dan inferensial. Hasil penelitian menunjukkan tiga hubungan yang positif dan signifikan. Pertama, terdapat hubungan yang positif dan signifikan antara Efikasi Diri dengan Efektivitas Pembelajaran guru PNS dengan nilai koefisien korelasi sebesar 0,536. Kedua, terdapat hubungan yang positif dan signifikan antara Supervisi Kepala Sekolah dengan Efektivitas Pembelajaran dengan nilai koefisien korelasi sebesar 0,519. Ketiga, terdapat hubungan yang positif dan signifikan antara Efikasi Diri dan Supervisi Kepala Sekolah secara berssama-sama dengan Efektivitas Pembelajaran dengan nilai koefisien korelasi sebesar 0,616.
\end{abstract}

Kata Kunci: Efikasi Diri; Supervisi Kepala Sekolah; Efektivitas pembelajaran

\section{STRENGTHENING LEARNING EFFECTIVENESS THROUGH SELF EFFICATION AND SUPERVISION OF SCHOOL HEADS}

\begin{abstract}
This study aimed to find the efforts to increase the effectiveness of learning through a study of its relationship with self-efficacy and principal supervision. The population of this study was 163 civil servant teachers, with a total sample of 116 teachers. It was determined by using the Slovin formula with an error tolerance of 5\%. The data was collected by using an instrument in the form of a questionnaire and analyzed with descriptive and inferential statistical analysis. The results showed that there were three positive and significant relationships. Firstly, there was a positive and significant relationship between selfefficacy and the learning effectiveness of PNS teachers with a correlation coefficient value of 0.536. Secondly, there was a positive and significant relationship between principal supervision and learning effectiveness with a correlation coefficient value of 0.519. Thirdly, there was a positive and significant relationship between self-efficacy and principal supervision together with learning effectiveness with a correlation coefficient value of 0.616.
\end{abstract}

Keywords: Self Efficacy; Principal Supervision; Learning effectiveness

\section{PENDAHULUAN}

Peningkatan kualitas pendidikan merupakan tujuan pendidikan di Indonesia. Dalam rangka mewujudkan pendidikan yang bermutu tentu tidak terlepas dari peranan berbagai pihak, salah satunya adalah peran tenaga pendidik. Tenaga pendidik merupakan suatu komponen penting dalam penyelenggaraan pendidikan, yang bertugas menyelenggarakan kegiatan mengajar, melatih, meneliti, mengembangkan, mengelola dan memberikan pelayanan teknis dalam bidang pendidikan. Dalam upaya peningkatan mutu pendidikan, aspek utama yang ditentukan adalah kualitas guru. Hal ini disebabkan guru merupakan titik sentral dalam pembaharuan dan peningkatan mutu pendidikan dalam usaha penguatan efektivitas pembelajaran maka efikasi diri dari seorang guru sangat berpengaruh pada kemampuan dirinya. Efektivitas pembelajaran merupakan pencapaian tujuan antara perencanaan pembelajaran dan hasil pembelajaran di mana dalam memilih tujuan yang hendak dicapai dan sasaran atau peralatan yang digunakan serta kemampuan yang dimiliki adalah tepat sehingga tujuan yang ingin di capai dengan hasil yang memuaskan

Agar efektivitas pembelajaran tercapai hendaknya guru mampu merencanakan, merakit, atau mempergunakan berbagai media sesuai dengan materi pembelajaran, penyajian informasi, partisipasi siswa, penilaian dan tindak lanjut. Ke tujuh menentukan muatan bahan ajar, bahan ajar yang telah disesuaikan dengan tingkat kemampuan siswa. Inti pokok Profesionalitas guru dalam profesinya sebagai tenaga mengajar, baik dan buruknya, runtut dan tidaknya guru dalam melaksanakan pembelajaran dipengaruhi oleh sejauh mana kesiapan rencana pembelajaran. Kedelapan, mampu menilai hasil belajar. Menilai 
hasil belajar merupakan bagian terakhir dari proses pembelajaran. Keberhasilan pendidikan tidak bisa dinilai dari outuputsemata. Jauh lebih penting daripada itu yakni perlu dipelajari keterlaksanaan fungsi-fungsi manajemen sekolah yang dimulai dari planning, organizing, actuating serta controlling (Suchyadi, Karmila, \& Safitri, 2019). Outuputpendidikan yang baik tidak akan lepas dari berjalannya fungsi-fungsi manajemen inti dengan baik pula. Bagaimana perencanaan-perencanaan yang dibuat oleh sekolah tentang sumber daya sekolah yang meliputi; man, money, method, machine, material dan information (Suchyadi et al., 2019).

Apabila guru menyiapkan strategi yang telah diuraikan di atas maka akan tercapai peningkatan mutu pendidikan. Peningkatan mutu pendidikan perlu diupayakan secara nyata dengan melaksanakan strategi pembelajaran sehingga meningkatkannya efektivitas pembelajaran di sekolah. Keefektivitas pembelajaran sebagai tindakan keberhasilan siswa untuk mencapai tujuan yang dapat membawa hasil belajar secara maksimal. Setiap organisasi pendidikan tentu melaksanakan program yang dimulai dari tahap perencanaan sampai pada evaluasi (Karmila \& Suchyadi, 2020). Berdasarkan hasil survai penelitian awal dengan menyebar kuesioner pada tanggal 26 November 2019 di sekolah Negeri dengan responden 30 guru sekolah da seKecamatan Cisarua Kabupaten Bogor Provinsi Jawa Barat, diperoleh data sebagai berikut: Sebanyak $40 \%$ belum mampu pengorganisasian materi pembelajaran. Sebanyak $55 \%$ belum memilih metode pembelajaran yang tepat. Sebanyak $50 \%$ membuat perencanaan dan persiapan yang belum tepat. Sebanyak $60 \%$ aktivitas siswa dalam pembelajaran kurang aktif. Sebanyak $60 \%$ guru belum kreatif dalam aplikasi media pembelajaran, kreativitas guru untuk meningkatkan kompetensinya di tengah pesatnya perkembangan ilmu dan teknologi, media pembelajaran yang disajikan guru.

Data tersebut menunjukkan bahwa efektivitas pembelajaran pada guru PNS dalam kegiatan pembelajaran belum optimal sehingga perlu adanya penguatan terhadap efektivitas pembelajaran dengan meningkatkan efikasi diri dan supervisi dari kepala sekolah, jika efektivitas pembelajaran optimal maka akan berdampak pada perolehan nilai yang memenuhi kriteria ketuntasan minimal serta dapat meningkatkan kualitas pendidikan, sebaliknya jika efektivitas pembelajaran belum optimal maka akan berdampak pada kualitas pendidikan yang rendah. Mengacu pada data hasil survei tersebut maka perlu diadakan penelitian yang berhubungan dengan penguatan efektivitas pembelajaran dengan meningkatkan efikasi diri dan supervisi kepala sekolah dengan harapan dapat memberi sumbangan pemikiran dari berbagai pihak yang memerlukan.

\section{Efektvitas Pembelajaran}

Efektivitas merupakan suatu konsep yang sangat penting karena memberikan gambaran mengenai keberhasilan seseorang dalam mencapai sasaran atau tingkat pencapaian tujuan- tujuan.(Azizah, 2016: 145-146). Efektivitas. Merupakan tingkat penggunaan sumber daya organisasi (tenaga, uang, teknologi, bahan baku) dimaksimalkan dengan maksud menaikkan hasil dari setiap unit dalam penggunaan sumber daya.(Ratnasari \& Yusnita, 2018:91-92). Efektivitas pembelajaran secara konseptual dapat diartikan sebagai perlakuan dalam proses pembelajaran yang memiliki keberhasilan usaha atau tindakan yang berpengaruh terhadap hasil belajar peserta didik.(Saputro, 2018: 29-37) Indikator - Indikator Efektivitas Pembelajaran Kriteria efektivitas yang digunakan dalam penelitian ini adalah apabila tiga aspek yang meliputi: (1) kemampuan guru dalam mengelola pembelajaran baik; (2) aktivitas siswa dalam pembelajaran baik; (3) hasil belajar siswa tuntas secara klasikal. Dengan syarat aspek ketuntasan belajar terpenuhi.

Susilo (2012: 51-54) Efektivitas pembelajaran adalah prilaku mengajar yang efektif ditunjukan oleh pendidik yang mampu memberikan pengalaman baru melalui pendekatan dan strategi khusus untuk mencapai tujuan pembelajaran. Efektivitas pembelajaran secara konseptual dapat diartikan sebagai perlakuan dalam proses pembelajaran. Efektivitas pembelajaran memiliki ciri-ciri : a) suasana yang dapat berpengaruh, atau hal yang berkesan terhadap penampilan; dan b) keberhasilan usaha atau tindakan yang berpengaruh terhadap hasil belajar siswa. (Haryoko, 2009: 1-10) Berdasarkan dari teori-teori di atas dapat disintesiskan bahwa efektivitas pembelajaran adalah prilaku keberhasilan pencapaian tujuan pembelajaran yang tepat pada hasil belajar peserta didik, dengan indikatornya adalah; 1. Pengorganisasian materi pelajaran, 2.Memilih metode pembelajaran yang tepat 3. Membuat perencanaan dan persiapan yang berkualitas, 4. Aktivitas siswa dalam pembelajaran, 5. Kreatif dalam aplikasi media pembelajaran

\section{Efikasi Diri}

Pengetahuan efikasi diri sangat penting (Hidayat, 2020). Efikasi diri mengacu pada kenyakinan yang dimiliki seseorang tentang kemampuan dirinya terhadap tindakan yang diperlukan untuk mencapai tuntutan dari kinerja. Indikator efikasi diri meliputi (a) keyakinan akan keterlibatan dalam tugas dengan disiplin, konsisten, dan tegas; (b) keyakinan atas kemampuannya dalam menghadapi tantangan atau kegagalan; (c) fokus terhadap tugas ketika menghadapi kegagalan, dan ulet tanpa kenal lelah; serta (d) rasa nyaman pada saat bekerja. Dewi (2012: 87-99) Efikasi diri adalah keyakinan individu mengenai kemampuan dirinya dalam melakukan tugas atau tindakan yang diperlukan untuk mencapai hasil tertentu. Efikasi diri pada diri tiap individu akan berbeda antara satu individu dengan yang lainnya berdasarkan tiga dimensi, yaitu tingkat, kekuatan, dan generalisasi. Rustan (2017: 163-179) Efikasi diri menunjukkan bahwa apa yang orang percaya mereka dapat atau tidak dapat lakukan berdampak kuat pada kinerja mereka. Mengembangkan dan memperkuat kepercayaan diri yang positif pada karyawan merupakan tujuan manajemen kinerja yang penting. Armstrong (2012: 152-153) Efikasi diri adalah kenyakinan yang dimiliki seseorang tenta kemampuan dirinya terhadap tin- dakan yang diperlukaIndikator efikasi diri meliputi (a) keyakinan akan keterlibatan dalam tugas dengan disiplin, konsisten, dan tegas; (b) keyakinan atas kemampuannya dalam menghadapi tantangan atau kegagalan; (c) fokus ter- hadap tugas ketika menghadapi kegagalan, dan ulet tanpa kenal lelah; serta (d) rasa nyaman pada saat bekerja. (Dewi, 2017:87-99) 
Berdasarkan teori - teori di atas dapat disintesiskan bahwa efikasi diri adalah keyakinan akan kecakapan dalam melaksanakan tugasnya untuk mencapai tujuan kerja. Adapun indikator dari Efikasi diri adalah sebagai berikut: 1) memiliki kecakapan diri,menyelesaikan tugas, 2) menetapkan perencanaan dan pengaturan diri dalam menyelesaikan tugas, 3) kekuatan terhadap usahanya dalam mewujudkan tujuan yang diharapkan, 4) memiliki keyakinan akan kecakapan untuk bertahan dalam usaha - usaha yang dilakukan untuk mencapai tujuan

\section{Supervisi Kepala Sekolah}

Pengetahuan dan keterampilan mensupervisi sangat penting (Purnamawati, 2020). Supervisi mengacu kepada serangkaian usaha pemberian bantuan, dalam bentuk layanan professional yang diberikan oleh supervisor, guna meningkatkan kualitas diri dan kualitas pelaksanaan tugasnya. Indikatornya adalah: 1) Pembinaan, pemberian motivasi, arahan, bimbingan; 2) Pemberian bantuan; 3) Pencapai tujuan; 4) Peningkatan pengembangan (development) kualitas; 5) Pengawasan serta perbaikan kinerja. (Widyastuti, 2016: 19-28). Kegiatan supervisi adalah kegiatan yang positif dan mulia, yaitu membantu guru. Supervisi tidaklah berarti menilai kinerja guru, sehingga terkesan mencari atau menemukan kelemahan/kekurangan guru dalam melaksanakan pembelajaran, seperti kesan negatif yang selama ini tertanam dalam pandangan para guru. Bahwa fungsi dan tujuan supervisi akademik ialah pengembangan profesionalisme, penumbuhan motivasi dan pengawasan kualitas. (Rosilawati, 2014: 57-62)

Supervisi kepala sekolah adalah serangkaian kegiatan membantu guru mengembangkan kemampuannya dalam mengelola proses pembelajaran untuk mencapai tujuan pembelajaran. Oleh karena itu, tujuan untuk meningkatkan kompetensi supervisi akademik yang meliputi (1) perencanaan program supervisi akademik, (2) pelaksanaan program supervisi akademik dan (3) menindaklanjuti program supervisi akademik. (Prasojo, 2007:1-34). Berdasarkan dari teori di atas dapat disintesiskan bahwa supervisi kepala sekolah adalah tindakan kepala sekolah dalam membantu guru untuk meningkatkan kualitas diri dan kualitas pelaksanaan tugasnya yang diukur dengan indikator 1) Merencanakan program supervisi, 2) Teknik supervisi yang tepat, 3) kecakapan membimbing dan membina, 4) Menindaklanjuti hasil supervisi

\section{METODE PENELITIAN}

Penelitian ini menggunakan metode kuantitatif dengan metode survei korelasional. Variabel bebas dalam penelitian ini yaitu Efikasi Diri $\left(\mathrm{X}_{1}\right)$ dan Supervisi Kepala Sekolah $\left(\mathrm{X}_{2}\right)$, sedangkan variabel terikat $(\mathrm{Y})$, adalah Efektivitas Pembelajaran. Populasi dalam penelitian ini yaitu Guru PNS SDN se-Kecamatan Cisarua. Dengan menggunakan teknik proporsional random sampling dan rumus Slovin, diperoleh sampel penelitian sebanyak 116 orang. Data hasil penelitian kuantitatif dianalisis menggunakan statistik deskriptif dan statistik inferensial. Statistik inferensial yang menggunakan analisis regresi-korelasi. Analisis data diawali dengan analisis persyaratan analisis, yaitu: uji normalitas galat taksir dan uji homogenitas varian, kemudian dilanjutkan dengan penetapan persamaan regresi, uji signifikansi persamaan regresi, linearitas regresi serta pengujian hipotesis dengan uji korelasi menggunakan tabel ANAVA.

\section{HASIL DAN PEMBAHASAN}

\section{Pengujian Persyaratan Analisis}

\section{Uji Normalitas}

Syarat data sampel berasal dari populasi berdistribusi normal adalah jika $\mathrm{L}_{\text {hitung }}<\mathrm{L}_{\text {tabel }}$ dengan taraf signifikan 0,05 . Hasil perhitungan normalitas galat taksiran variabel Efektivitas Pembelajaran atas Efikasi Diri diperoleh nilai $\mathrm{L}_{0}$ maksimum 0,076 sementara $\mathrm{L}_{t}$ sebesar 0,083. Dengan demikian galat baku taksiran variabel Efektivitas Pembelajaran atas variabel Efikasi Diri berdistribusi normal. Hasil perhitungan normalitas galat taksiran variabel Efektivitas Pembelajaran atas Supervisi Kepala Sekolah diperoleh nilai $\mathrm{L}_{0}$ maksimum 0,057 sementara $\mathrm{L}_{\mathrm{t}}$ sebesar 0,083. Dengan demikian galat baku taksiran variabel Efektivitas Pembelajaran atas Supervisi Kepala Sekolah berdistribusi normal.

\section{Uji Homogenitas}

Syarat varians homogen adalah jika $\chi 2$ hitung $<\chi 2$ tabel dengan taraf signifikansi 0,05 . Hasil homogenitas varians variabel Efektivitas Pembelajaran atas atas Efikasi Diri diperoleh nilai $\chi 2$ hitung sebesar 52,05 sedangkan $\chi 2$ tabel pada taraf signifikansi 5\% sebesar 106,39, sehingga dapat disimpulkan bahwa kelompok data Efektivitas Pembelajaran atas atas variabel Efikasi Diri berasal dari populasi yang homogen. Hasil homogenitas varians variabel Efektivitas Pembelajaran atas Supervisi Kepala Sekolah diperoleh nilai $\chi 2$ hitung sebesar 50,18 sedangkan $\chi 2$ tabel pada taraf signifikansi 5\% sebesar 70,99. dikarenakan $\chi 2$ hitung $<\chi 2$ tabel, dapat disimpulkan bahwa kelompok data Efektivitas Pembelajaran atas variabel Supervisi Kepala Sekolah berasal dari populasi yang homogen.

\section{Pengujian Hipotesis}

\section{Hubungan Antara Efikasi Diri ( $\left.\mathrm{X}_{1}\right)$ dengan Efektivitas Pembelajaran (Y).}

Dari hasil perhitungan analisis korelasi, diketahui bahwa nilai koefesien korelasi antara Efikasi Diri dengan Efektivitas Pembelajaran, sebesar 0,598 dan nilai thitung sebesar 9,057 serta nilai ttabel pada $\alpha=0,05$ sebesar 1,66 dan $\alpha=0,01$ sebesar 2,35. Oleh karena itu nilai thitung lebih besar dari nilai ttabel maka dengan demikian H0 ditolak dan H1 diterima. Artinya bahwa 
terdapat hubungan positif antara Efikasi Diri dengan Efektivitas Pembelajaran.

\section{Hubungan antara Supervisi Kepala Sekolah $\left(\mathbf{X}_{2}\right)$ dengan Efektivitas Pembelajaran $(\mathbf{Y})$.}

Dari hasil perhitungan analisis korelasi, diketahui nilai koefesien korelasi antara efikasi diri dengan Supervisi Kepala Sekolah, sebesar 0,519 dan nilai $t_{\text {hitung }}$ sebesar 6,485 serta nilai $t_{\text {tabel }}$ pada $\alpha=0,05$ sebesar 1,66 dan $\alpha=0,01$ sebesar 2,35. Oleh karena itu nilai $t_{\text {hitung }}$ lebih besar dari nilai $t_{\text {tabel }}$ maka dengan demikian $\mathrm{H}_{0}$ ditolah dan $\mathrm{H}_{1}$ diterima. Artinya bahwa terdapat hubungan positif antara Supervisi Kepala Sekolah dengan Efektivitas Pembelajaran.

\section{Hubungan antara Efikasi Diri (X1) dan Supervisi Kepala Sekolah (X2) secara bersama-sama dengan Efektivitas Pembelajaran (Y)}

Korelasi variabel Efikasi Diri $\left(\mathrm{X}_{1}\right)$ dan Supervisi Kepala Sekolah $\left(\mathrm{X}_{2}\right)$ secara bersama- sama dengan Efektivitas Pembelajaran (Y) ditentukan oleh nilai koefesien determinasi $\left(\mathrm{R}_{\mathrm{y} 1.2}{ }^{2}\right)$. Nilai koefesien determinasi menunjukkan besarnya kontribusi variabel Efikasi Diri $\left(\mathrm{X}_{1}\right)$ dan Supervisi Kepala Sekolah $\left(\mathrm{X}_{2}\right)$ dapat mempengaruhi variabel Efektivitas Pembelajaran (Y). Berdasarkan hasil estimasi diperoleh nilai $\mathrm{R}_{\mathrm{y} 1.2}{ }^{2}$ sebesar 0,380. Hal ini menunjukkan bahwa 38\% variabel Efektivitas Pembelajaran $(\mathrm{Y})$ dapat dipengaruhi oleh variabel Efikasi Diri $\left(\mathrm{X}_{1}\right)$ dan Supervisi Kepala Sekolah $\left(\mathrm{X}_{2}\right)$. Resistensi hubungan diantara variabel Efikasi Diri $\left(\mathrm{X}_{1}\right)$ dan Supervisi Kepala Sekolah $\left(\mathrm{X}_{2}\right)$ secara bersama- sama dengan variabel Efektivitas Pembelajaran (Y) ditentukan oleh koefesien korelasi $\mathrm{R}_{\mathrm{y} 1.2}{ }^{2}$ sebesar 0,616. Pengujian hipotesis yang membuktikan terdapat hubungan positif variabel Efikasi Diri $\left(\mathrm{X}_{1}\right)$ dan Supervisi Kepala Sekolah $\left(\mathrm{X}_{2}\right)$ secara bersama-sama dengan variabel Efektivitas Pembelajaran (Y) diperlukan uji signifikan koefesien korelasi dengan menggunakan uji F. tolak ukur pengujian signifikan koefesien yaitu $\mathrm{F}_{\text {hitung }}>\mathrm{F}_{\text {tabel. }}$

\section{Korelasi Parsial}

Hasil uji korelasi parsial antara Efikasi Diri $\left(\mathrm{X}_{1}\right)$ dengan Efektivitas Pembelajaran (Y) dan Supervisi Kepala Sekolah $\left(\mathrm{X}_{2}\right)$ dikontrol oleh koefisien korelasi parsial $\left(\mathrm{R}_{\mathrm{y} 1}{ }^{2}\right)=0,389$. Berdasarkan uji signifikansi, nilai tersebut sangat signifikan bahwa $\mathrm{t}_{\text {hitung }}$ 9,057 lebih besar dari $t_{\text {tabel }}$ pada taraf signifikasi $\alpha=0,05$ sebesar 1,66 dan $\alpha=0,01$ sebesar 2,35. Hal ini berarti bahwa hubungan antara Efikasi Diri $\left(\mathrm{X}_{1}\right)$ dengan Efektivitas Pembelajaran (Y) tidak dipengaruhi secara signifikan oleh Supervisi Kepala Sekolah $\left(\mathrm{X}_{2}\right)$. Hasil uji korelasi parsial antara Supervisi Kepala Sekolah $\left(\mathrm{X}_{2}\right)$ dengan Efektivitas Pembelajaran $(\mathrm{Y})$ dan Efikasi Diri $\left(X_{1}\right)$ dikontrol oleh koefisien korelasi parsial $\left(\mathrm{R}_{\mathrm{y} 2}{ }^{1}\right)=0,361$. Berdasarkan uji signifikansi, nilai tersebut tidak signifikan, bahwa $t_{\text {hitung }} 6,485$ lebih kecil dari $t_{\text {tabel }}$ pada taraf signifikasi $\alpha=0,05$ sebesar 1,66 dan $\alpha=0,01$ sebesar 2,35. Hal ini berarti variabel Efikasi Diri $\left(\mathrm{X}_{1}\right)$ berpengaruh secara signifikan terhadap hubungan antara Supervisi Kepala Sekolah $\left(\mathrm{X}_{2}\right)$ dan Efektivitas Pembelajaran (Y).

\section{Pembahasan}

\section{Hubungan Efikasi Diri ( $\left.\mathrm{X}_{1}\right)$ dengan Efektivitas Pembelajaran (Y)}

Kekuatan hubungan Efikasi Diri dengan Efektivitas Pembelajaran dapat terlihat pada hasil uji korelasi dengan nilai koefesien sebesar 0,536. Keragaman yang ada pada Efektivitas Pembelajaran memiliki kaitan dengan Efikasi Diri, hal tersebut dapat dilihat dari nilai koefesien determinasi sebesar 0,2871 sehingga keragaman yang ada pada Efektivitas Pembelajaran dapat dijelaskan oleh Efikasi Diri dengan kontribusi sebesar 28\%. Sedangkan $72 \%$ dipengaruhi oleh faktor lain diluar Efikasi Diri. Penelitian ini juga mendukung penelitian terdahulu yang dilakukan oleh Tuhardjo, Juliardi, Rafsanjani, Nuris, Department of Accounting, Universitas Negeri Malang (2016:126-128). Hasil pengujian hipotesis, diketahui bahwa variabel efektivitas belajar memiliki signifikansi level <0,01 dan koefisien positif. Ini menunjukkan bahwa hipotesis pertama (H1) dalam penelitian ini diterima padaa tingkat signifikansi $1 \%$, artinya ada pengaruh positif yang signifikan terhadap efektivitas belajar untuk Akuntansi Keuangan Menengah I tentu saja hasil pembelajaran. Hal yang sama terjadi pada variabel self-efficacy yang memiliki tingkat signifikansi $<0,05$ dan koefisien positif. Ini menunjukkan yang kedua Hipotesis (H2) dalam penelitian ini diterima pada taraf signifikansi 5\%, artinya terdapat signifikan positif pengaruh self-efficacy untuk hasil belajar Akuntansi Keuangan Menengah 1.

\section{Hubungan antara Supervisi Kepala Sekolah $\left(\mathbf{X}_{2}\right)$ dengan Efektivitas Pembelajaran (Y)}

Kekuatan hubungan antara Supervisi Kepala Sekolah dengan Efektivitas Pembelajaran tercermin pada nilai koefisien korelasi $\left(\mathrm{R}_{\mathrm{yl}}\right)$ sebesar 0,519. Begitu pula keragaman pada Efektivitas Pembelajaran yang terkait erat dengan Supervisi Kepala Sekolah, yang tercemin pada nilai koefisien determinasinya $\left(\mathrm{R}_{\mathrm{yl}}{ }^{2}\right)$ sebesar 0,2695 menunjukkan variabel Supervisi Kepala Sekolah memberikan kontribusi sebesar 27\% terhadap kenaikan Efektivitas Pembelajaran, sedangkan 73\% disumbangkan oleh faktor- faktor lainnya. Hasil penelitian ini sejalan dengan hasil penelitian yang dilakukan oleh Yulianti (2018:79-81) tentang Pengaruh Supervisi Akademik Kepala Sekolah, Iklim Sekolah dan Etos Kerja Guru terhadap Efektivitas Pembelajaran Di SMA Negeri Kabupaten Tulang Bawang memberikan kesimpulan bahwa terdapat hubungan positif secara signifikan anatara supervisi akademik dengan perilaku efektivitas pembelajaran yang dijukan dengan taraf signifilan 5\% (0,05) diperoleh angka rtabel sebesar 0,444. Berdasarkan uraian di atas maka dapat disimpulkan bahwa terdapat hubungan positif yang siginifikan antara Supervisi Kepala Sekolah dengan Efektivitas Pembelajaran. Variabel Supervisi Kepala Sekolah pada suatu 
sekolah merupakan salah satu faktor yang juga menentukan dalam meningkatkan Efektivitas Pembelajaran guru PNS Sekolah Dasar se-Kecamatan Cisarua.

\section{Hubungan antara Efikasi Diri $\left(X_{1}\right)$ dan Supervisi Kepala Sekolah $\left(X_{2}\right)$ secara bersama-sama dengan Efektivitas Pembelajaran (Y)}

Dalam penelitian ini juga diperoleh fakta bahwa terdapat hubungan yang positif dan sangat signifikan antara Efikasi Diri dan Supervisi Kepala Sekolah secara bersama-sama dengan Efektivitas Pembelajaran, dapat dinyatakan dalam bentuk persamaan garis lurus $\hat{\mathrm{Y}}=22,033+0,419 \mathrm{X}_{1}+0,370 \mathrm{X}_{2}$. Hal ini menunjukkan bahwa setiap kenaikan satu unit Efikasi Diri dan Supervisi Kepala Sekolah secara bersama-sama akan menaikkan 0,789 unit Efektivitas Pembelajaran. Selain itu, persamaan garis lurus ini juga mengungkapkan bahwa tanpa kehadiran variabel Efikasi Diri dan Supervisi Kepala Sekolah secara bersama-sama telah memiliki Efektivitas Pembelajaran sebesar 22,033 unit. Kekuatan hubungan antara Efikasi Diri dan Supervisi Kepala Sekolah secara bersama-sama dengan Efektivitas Pembelajaran menghasilkan koefisien korelasi $\left(\mathrm{r}_{\mathrm{y} \cdot 12}\right)$ sebesar 0,616. Begitu pula dengan keragaman pada Efikasi Diri dan Supervisi Kepala Sekolah secara bersama-sama dengan Efektivitas Pembelajaran, yang dicerminkan dengan nilai koefisien determinasinya $\left(\mathrm{R}_{\mathrm{y} \cdot 12}{ }^{2}\right)$ sebesar 0,380 menunjukkan variabel antara Efikasi Diri dan Supervisi Kepala Sekolah secara bersama-sama memberikan kontribusi sebesar 38\% terhadap keragaman pada Efektivitas Pembelajaran, dan untuk $62 \%$ lainnya disumbangkan oleh faktor-faktor yang lainnya.

Hasil analisis regresi ganda diperoleh bahwa terdapat hubungan yang positif dan sangat signifikan, hal ini dimaknai bahwa jika Efikasi Diri dan Supervisi Kepala Sekolah baik maka Efektivitas Pembelajaran guru akan semakin tinggi. Hal ini dipersepsikan bahwa lingkungan sekolah yang nyaman, ketepatan menyusun program pengajaran, pengelolaan kondisi kelas yang baik serta ketepatan penggunaan media pembelajaran dan sumber belajar serta keterlibatan siswa di dalam kelas, ketepatan pelaksanaan evaluasi adalah cara menciptakan pembelajaran yang efektif. Efektivitas pembelajaran akan terjadi jika dilakukan bersama oleh anggota sekolah sehingga dapat tercipta pembelajaran yang efektif sehingga tujuan pembelajaran tercapai. Berdasarkan uraian pembahasan di atas maka dapat disimpulkan bahwa bahwa faktor Efikasi Diri $(0,536)$ lebih dominan dari faktor Supervisi Kepala Sekolah (0,519). Selain itu, Efikasi Diri dan Supervisi Kepala Sekolah pada suatu sekolah merupakan faktor yang menentukan dalam Efektivitas Pembelajaran guru terhadap sekolah. Hubungan positif yang sangat signifikan antara antara Efikasi Diri $\left(\mathrm{X}_{1}\right)$ dan Supervisi Kepala Sekolah $\left(\mathrm{X}_{2}\right)$ secara bersama-sama dengan Efektivitas Pembelajaran (Y), yang bermakna semakin tinggi Efikasi Diri dan Supervisi Kepala Sekolah seara bersama-sama, maka semakin tinggi Efektivitas Pembelajaran guru PNS Sekolah Dasar Negeri se-Kecamatan Cisarua.

\section{SIMPULAN}

Hasil penelitian menunjukkan bahwa terdapat hubungan yang positif dan signifikan antara Efikasi Diri dengan Efektivitas Pembelajaran dengan kekuatan hubungan Ry1=0,536 dan terdapat hubungan yang positif antara Supervisi Kepala Sekolah dengan Efektivitas Pembelajaran, dengan kekuatan hubungan Ry2 =0,519. Hal ini mencerminkan bahwa, untuk meningkatkan Efektivitas Pembelajaran guru dilakukan upaya dengan cara meningkatkan Efikasi Diri dan Supervisi Kepala Sekolah.

\section{REFERENSI}

Armstrong, S. (2012). Amstrong's Handbook of Human Resource Management Practice.

Azizah, I. M. (2016). Efektivitas Pembelajaran menggunakan Permainan Tradisional terhadap Motivasi dan Hasil Belajar Materi Gaya di Kelas IV MIN Ngronggot Nganjuk. Dinamika Penelitian, 16.

Bahri, S. (2014). Supervisi Akademik dalam Peningkatan Profesionalisme Guru, V, 100-112.

Dewi, R. (2012). Kinerja Kepala Sekolah: Pengaruh Kepemimpinan Transformasional dan Efikasi Diri. Jurnal Ilmu Pendidikan, (8).

Dewi, R. P. (2017). Hubungan Efikasi Diri denan Pengambilan Keputusan Karir pada Mahasiswa Tingkat Akhir Fakultas Psikologi Universitas Mercu Buana Yogyakarta, 19(2), 87-99.

Hidayat, Rais, Yuyun Elizabeth Patras, Griet Helena. (2020). Analysis on Items of Lecturer Self-Efficacy Instrument Using Rasch Modeling. Advances in Social Science, Education and Humanities Research, volume 400, 310-316.

Haryoko, S. (2009). Efektivitas Pemanfaatan Media Audio-Visual Sebagai Alternatif Optimalisasi Model Pembelajaran. Jurnal Edukasi, 5, 1-10.

Karmila, N., \& Suchyadi, Y. (2020). Supervisi Pendidikan Di Sekolah Alam Bogor. Jurnal Pendidikan Dan Pengajaran Guru Sekolah Dasar (JPPGuseda), 03, 31-33. Retrieved from http://journal.unpak.ac.id/index.php/jppguseda

Purnamawati, Risa Fahriyani , Rais Hidayat, Henny Suharyati. (2020). Development of Supervision Instrument Application Model through the Utilization of Android-Based Technology for School Heads. International Journal of Global Operations Research, Vol. 1, No. 4, pp. 143-150, 2020.

Rosilawati, T. (2014). Supervisi Akademik dalam Upaya Peningkatan Motivasi Guru Menyusun Perangkat Persiapan Pembelajaran. Jurnal Penelitian Tindakan Sekolah Dan Kepengawasan, 1(2), 57-62.

Rustan, H. T. dan E. (2017). Orientasi Religiusitas dan Efikasi Diri dalam Hubungannya dengan Kebermaknaan Pendidikan Agama Islam pada Mahasiswa IAIN Palopo. Jurnal Studi Agama Dan Masyarakat, 13, 163-179.

Saputro, Trimo, S. L. (2018). Efektivitas Metode Pembelajaran Quantum Learning terhadap Kemampuan Berpikir Tingkat 
Tinggi Peserta Didik Kelas X Ma Nurul Islam Gunung Sari Ulubelu Tanggamus. Indonesian Journal of Science and Mathematics Education, 01(2), 29-37.

Suchyadi, Y., Karmila, N., \& Safitri, N. (2019). Kepuasan Kerja Guru Ditinjau Dari Peran Supervisi Kepala Sekolah Dasar Negeri Di Kecamatan Bogor Utara. JPPGuseda | Jurnal Pendidikan \& Pengajaran Guru Sekolah Dasar, 2(2), 91-94. https://doi.org/10.33751/jppguseda.v2i2.1453

Suhayati, I. Y. (2013). Supervisi Akademik Kepala Sekolah, Budaya Sekolah dan Kinerja Mengajar Guru, (1), 86-95.

Susilo, F. A. (2012). Peningkatan Efektivitas pada Proses Pembelajaran.

Warsita, B. (2008). Teknologi Pembelajaran Landasan dan Aplikasinya. Jakarta: Rineka Cipta.

Widyastuti, M. (2016). Pengaruh Supervisi Kepala Sekolah dan Pengetahuan Pedagogik Terhadap Komitmen Profesi Guru. Faktor Jurnal Ilmiah Kependidikan, 3, 19-28.

Yulita, H. (2014). Faktor-Faktor yang Mempengaruhi Efektifitas dan Motivasi Mahasiswa dalam Menggunakan Metode Pembelajaran E-Learning. Business \& Management Journal Bunda Mulia, 10(1), 106-119. 